\title{
The future of crude oil and hard coal in the aspect of Poland's energy security
}

ABSTRACT: The article presents a synthetic analysis of the crude oil market in Poland. As of today, this safety is provided mainly on the basis of native lignite and hard coal resources. However, the analysis of the hard coal market conducted by the authors indicates that the carried out mining restructuring (among others) led to an excessive reduction of mining volume and employment level in the hard coal mining sector. This led to a precedent situation when Poland became an importer of this energy carrier. In addition, the European Union's requirements for greenhouse gas emissions must be taken into account. In connection with the above, it is necessary to search for new energy sources or technologies that enable hard coal to meet the requirements. It is possible to apply the so-called clean coal technologies that allow the greenhouse gas emissions generated during coal combustion to be reduced. As of today, they are not used on a mass scale, because the use of this type of technology involves additional financial expenses. However, taking into account that technologies have been growing faster and faster, are modernized in a shorter time, making a breakthrough discovery took hundreds of years, now it is often a few months, clean coal technologies can become the optimal solution in the near future. It is also necessary to diversify the sources of obtaining imported energy carriers.

The article describes coal and crude oil in terms of their mutual substitution. The article is a continuation of research conducted by the authors. Previous publications presented considerations on analogous topics related to natural gas and renewable energy sources. The crude oil market in Poland was analyzed and forecasts for oil extraction and the demand in the world and Poland by 2023 were presented. The SARIMA model was also created. The model made it possible to obtain oil an prices forecast.

KEYWORDS: crude oil market, energy resources, ARIMA model

\footnotetext{
${ }^{1}$ Silesian University of Technology, Faculty of Mining and Geology, Department of Electrical Engineering and Industrial Automation, Gliwice, e-mail: aurelia.rybak@polsl.pl, anna.manowska@polsl.pl
} 


\section{Introduction}

While deliberating on Poland's energy security, the fact that for the next few years coal will serve as its guarantor cannot be omitted. However, taking into account the necessity of complying the requirements imposed by the European Union in respect of greenhouse gas emissions (EMR 2011), the possibility of coal substitution should be considered (Kuchler and Bridge 2018; Gawlik et al. 2015). The authors in their previous articles took on making an analysis of natural gas and renewable energy sources as the substitutes of coal. In this publication, the emphasis is put on crude oil as a carrier of primary energy which may take the place of coal in Poland's energy mix. In addition, a reverse situation, in which the necessity of substituting crude oil by hard coal would occur, was taken into consideration. Energy security was defined in the Act on Energy Law as a state of the economy that enables covering consumers' current and perspective demand for fuel and energy in a technically and economically justified manner and in compliance with the requirements of environmental protection (PE [Energy Law] 2006). Having the above definition in mind, the following factors were taken into consideration in the analysis:

$\downarrow$ the amount of native resources,

$\checkmark$ crude oil prices,

$\checkmark$ the ecological aspect of its use;

$\checkmark$ availability.

\section{Crude oil market analysis}

There are 86 documented deposits of crude oil in Poland mainly in the Polish Lowland, the foreland of the Carpathian Mountains and in the area of the Polish Exclusive Economic Zone. Moreover, the world's oldest area of crude oil extraction is situated in the geographic area of Poland (in the Carpathian Mountains). The exploitable reserves amount to 22,029.05 thousand tons (PIG-PIB [Polish Geological Institute - National Research Institute] 2017). Data that was used in the conducted analyses comes from the BP Statistical Review of World Energy (SRWE 2018).

The biggest deposits of crude oil are found outside our country. Almost half of the proven crude oil reserves are found within the area of three countries: Canada, Venezuela, Saudi Arabia (Fig. 1). Russia, which is the main crude oil supplier to Poland, contributes a share of $6.4 \%$ to the world's reserves. Poland imports crude oil mainly from Russia (about 80\% in 2017), but also from: Saudi Arabia, Iran, Iraq, Kazakhstan, Lithuania, and Norway. The share of Russian oil has fallen in recent years. Polish refineries systematically introduce an increasing amount of crude oil from sources other than Russia, including Saudi Arabia and Iraq. In order to increase the level of Poland's energy security, the suppliers and routes of acquiring crude oil should be diversified. 
It enables the import of crude oil by sea route which gives the opportunity of acquiring the resource from e. g. Azerbaijan.

Since 1980, the amount of crude oil resources in the European Union has decreased twice. This is caused by the shrinkage of resources in the North Sea. Although they were discovered only in 1969, these resources are depleting quickly (Ney 2006). According to cautious estimates, the world's crude oil resources should last for about 40 years.

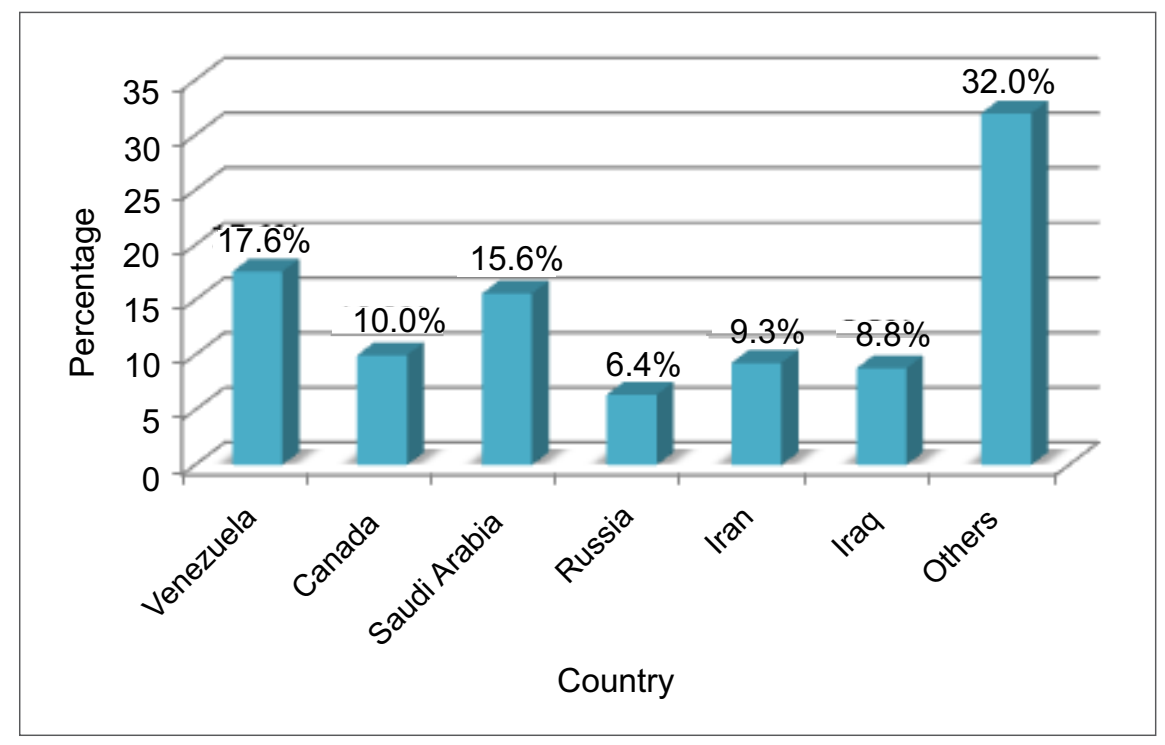

Fig. 1. Countries with the highest confirmed share of oil resources in the world (SRWE 2018)

Rys. 1. Państwa z najwyższym potwierdzonym udziałem zasobów ropy naftowej na świecie

The PKN Orlen group is the largest producer of products based on crude oil in Poland. PKN Orlen possesses $70 \%$ of the oil refinery production capacity in our country (Orlen 2018). The ORLEN Group has conducted exploration and production activities in North America since 2013. The average production in the Q2 of 2017 remained at 13,800 BOE/D. Through Lotos Exploration and Production Norge, the second largest oil company in Poland conducts exploration and production work in the field of oil exploitation in the area of the Norwegian Continental Shelf.

In the case of natural gas and crude oil, the lack of native sources and dependence of import on one supplier, the Russian Federation constitutes the major problem (Fig. 2). This is the largest crude oil supplier to Europe. Crude oil is also imported from Africa and the CIS countries (Commonwealth of Independent States).

Lignite (about 10\%), hard coal, natural gas, and crude oil have the largest share in production of primary energy consumed in Poland (Fig. 3). Depending on the carrier, Poland's energy security shapes variously. In order to characterize this relation, an indicator of energy dependence was used. 


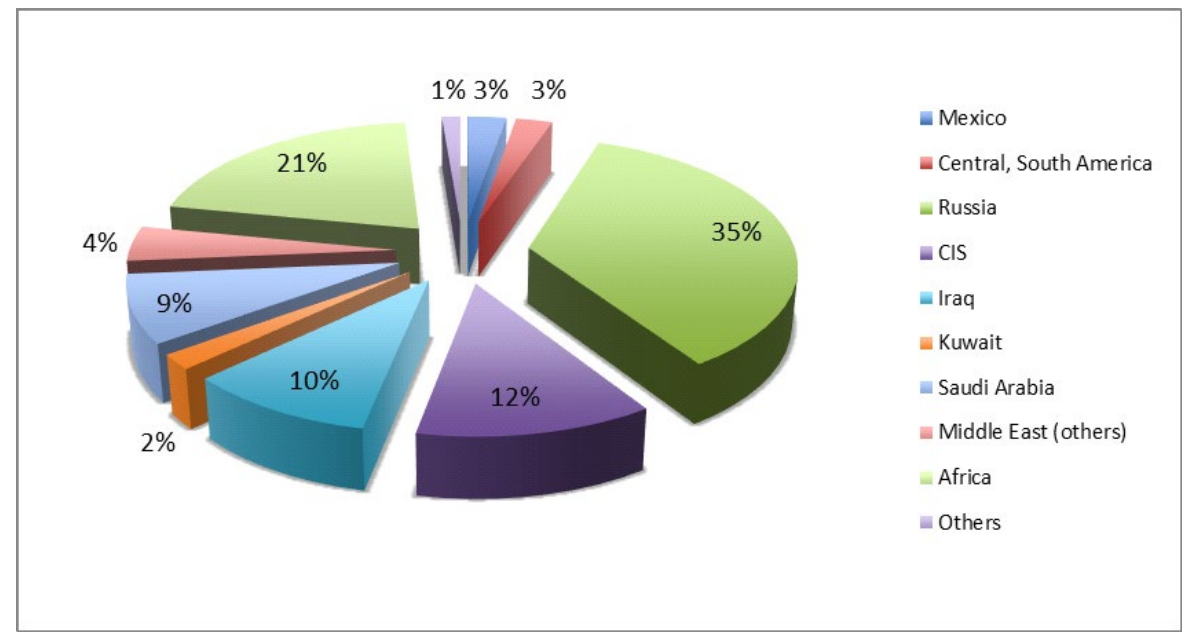

Fig. 2. Crude oil import sources to Europe in 2017 (SRWE 2018)

Rys. 2. Źródła importu ropy naftowej do Europy w roku 2017

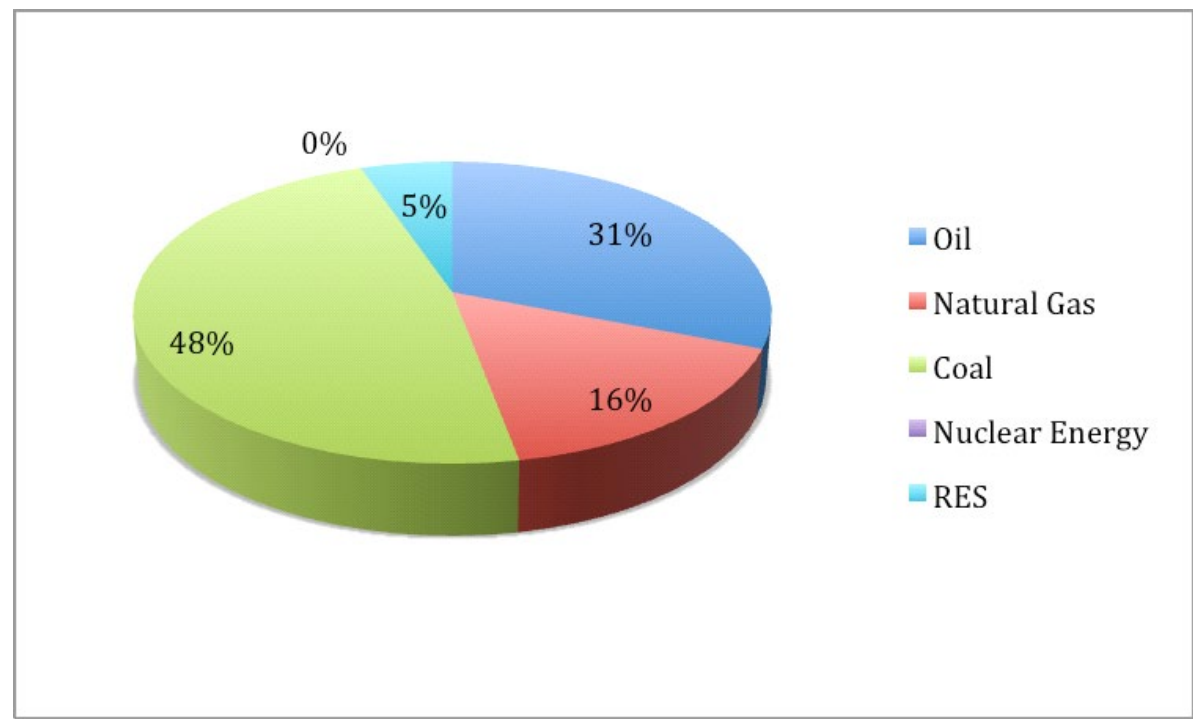

Fig. 3. Primary energy consumption in Poland in 2017 (SRWE 2018)

Rys. 3. Konsumpcja energii pierwotnej w Polsce w roku 2017

The indicator of Poland's energy dependence on crude oil import was calculated as the proportion of imported crude oil to national consumption of energy that comes from this carrier (Leszczyński 2012). The degree of dependence of the Polish economy on the import of this primary energy carrier amounts to $96 \%$. The degree of general energy dependence on import for 


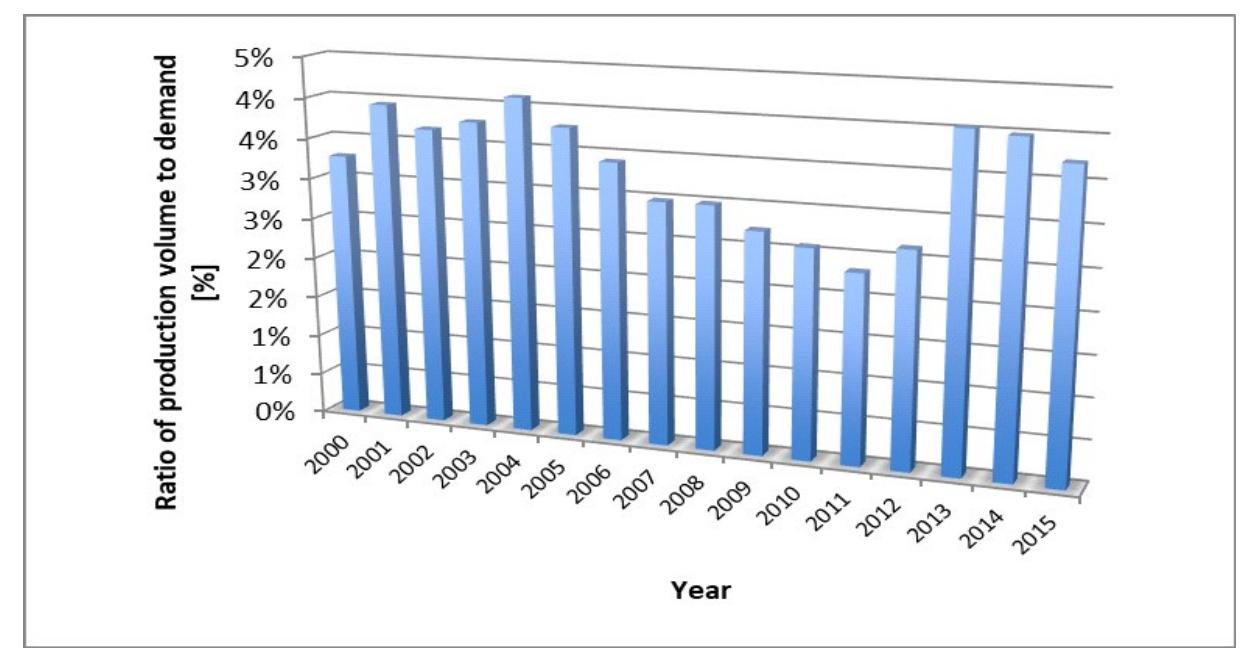

Fig. 4. The ratio of coal production to the amount of crude oil demand in Poland (SRWE 2018)

Rys. 4. Stosunek wydobycia do wielkości zapotrzebowania na ropę naftową w Polsce

crude oil, gas, and coal assumes much more favorable result which amounts to ca. $30 \%$. It should be noted that the level of this indicator was around 19\% in 2005 (EUROSTAT 2017). This is possible owing to the Polish coal resources. Figure 4 presents the proportion of the amount of crude oil production in Poland to the amount of demand for this energy carrier. The chart presents this relation since 2000 . The proportion does not exceed $4 \%$ analyzed period.

Crude oil production in Poland has remained at a constant level for many years. The input of the native production to the total demand is so scarce that the analysis of the changes in the amount of crude oil production should be based rather on the level of extraction on the global scale. In Poland, the demand for crude oil is almost entirely covered by import.

Since 1965, the amount of crude oil production in the world has increased almost three times (SRWE 2018). For the needs of this article, the authors created a few forecast models to verify how the analyzed phenomena will be developing in the nearest future on a national and world scale. For this purpose, ARIMA models and a SARIMA model that regards seasonal fluctuations were used. The distribution of residual models normality was proved by the Doornik-Hansen test, while the lack of residual autocorrelations was proved by the Ljung-Box tests (Zeliaś et al. 2004; Kot et al. 207; Kufel 2004). Non-stationary time series were brought to stationary form by differentiation. The selection of the best model was also possible thanks to information criteria such as AIC (Akaike Information Criterion), BIC (Bayesian Information Criterion), the Hannan -Quinn Information Criterion (Piłatowska 2010).

The forecast for the amount of crude oil production demonstrates a growing trend which will be maintained in the coming years if the time series is still influenced by the same environmental factors.

Ex post forecast accuracy measures demonstrate that the model is characterized by high accuracy: 


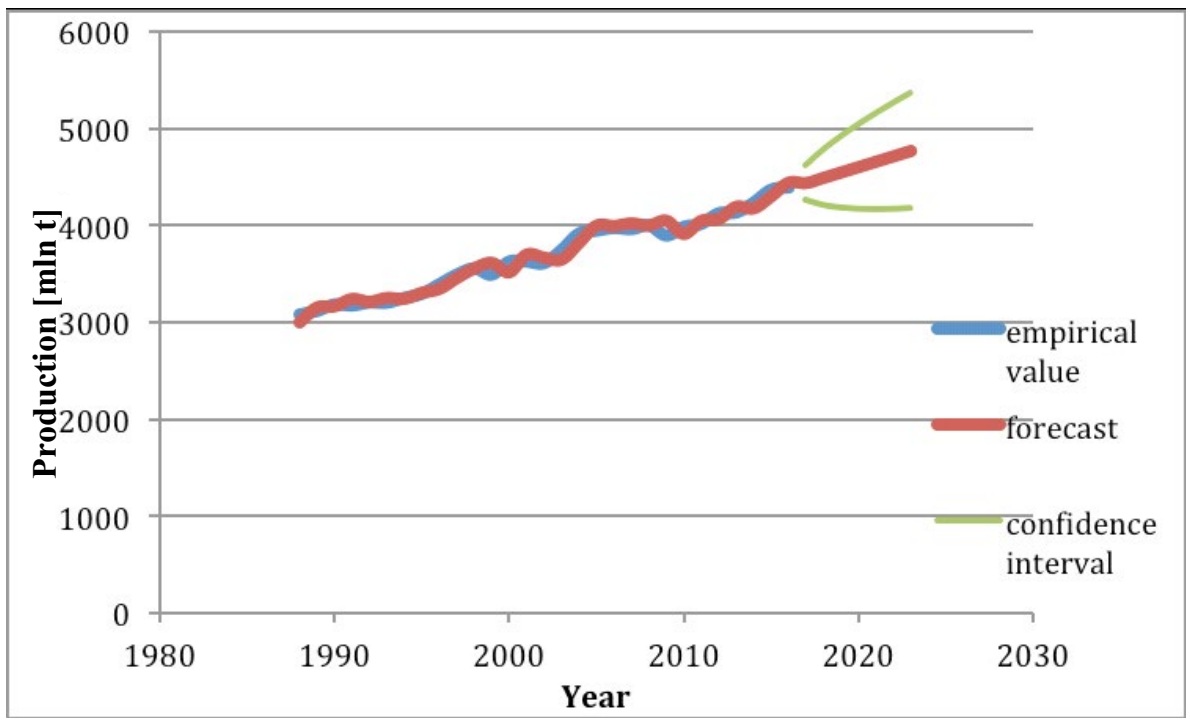

Fig. 5. Oil production in the world forecast by the year 2023, ARIMA $(1,1,0)$ model (SRWE 2018)

Rys. 5. Prognoza wielkości wydobycia ropy naftowej na świecie do roku 2023, model ARIMA $(1,1,0)$

$\checkmark$ The mean percentage error MPE $=0.6 \%$.

$\checkmark$ The mean absolute percentage error MAPE $=1.37 \%$.

$\checkmark$ The amount of the global demand for crude oil is characterized by a similar trend. The forecast by the year 2020 demonstrates that the growing tendency of the time series will also be maintained.

Accuracy measures:

\ The mean percentage error MPE $=-0.25 \%$.

४ The mean absolute percentage error MAPE $=0.98 \%$.

The time series of the amount of crude oil production and sales in the world are highly correlated with each other. The Pearson correlation coefficient is close to 1 and amounts to $99.8 \%$ in their case. This means that the amount of production is flexibly adapted to changes in crude oil demand. The course of the time series of crude oil demand in our country is also of a growing nature, however, larger deviations from the mean value over the years can be noticed. Figure 7 presents the forecast for crude oil demand in Poland with the confidence interval by the year 2020.

$\downarrow$ The mean percentage error MPE $=1.11 \%$.

$\checkmark$ The mean average percentage error MAPE $=4.68 \%$.

It was established that in comparison with the latest known observation the demand would increase in the determined forecast horizon by $8 \%$.

After dramatic price decreases in recent years, crude oil has begun to make up its losses and at the beginning of the year 2018, the price exceeded USD 66 per barrel. The price is currently around USD 70 per barrel. It is caused mainly by the steps taken by OPEC and Russia that con- 


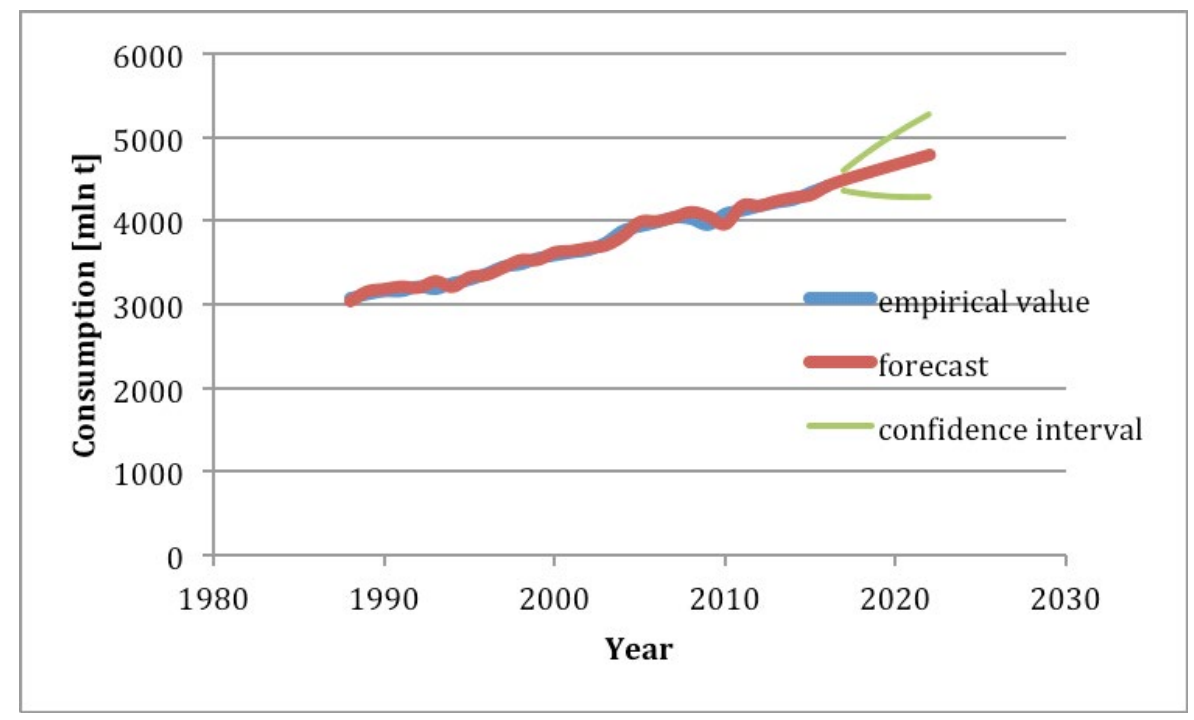

Fig. 6. Forecast of oil consumption in the world by 2023, ARIMA $(1,1,0)$ model (SRWE 2018)

Rys. 6. Prognoza konsumpcji ropy naftowej na świecie do roku 2023, model ARIMA $(1,1,0)$

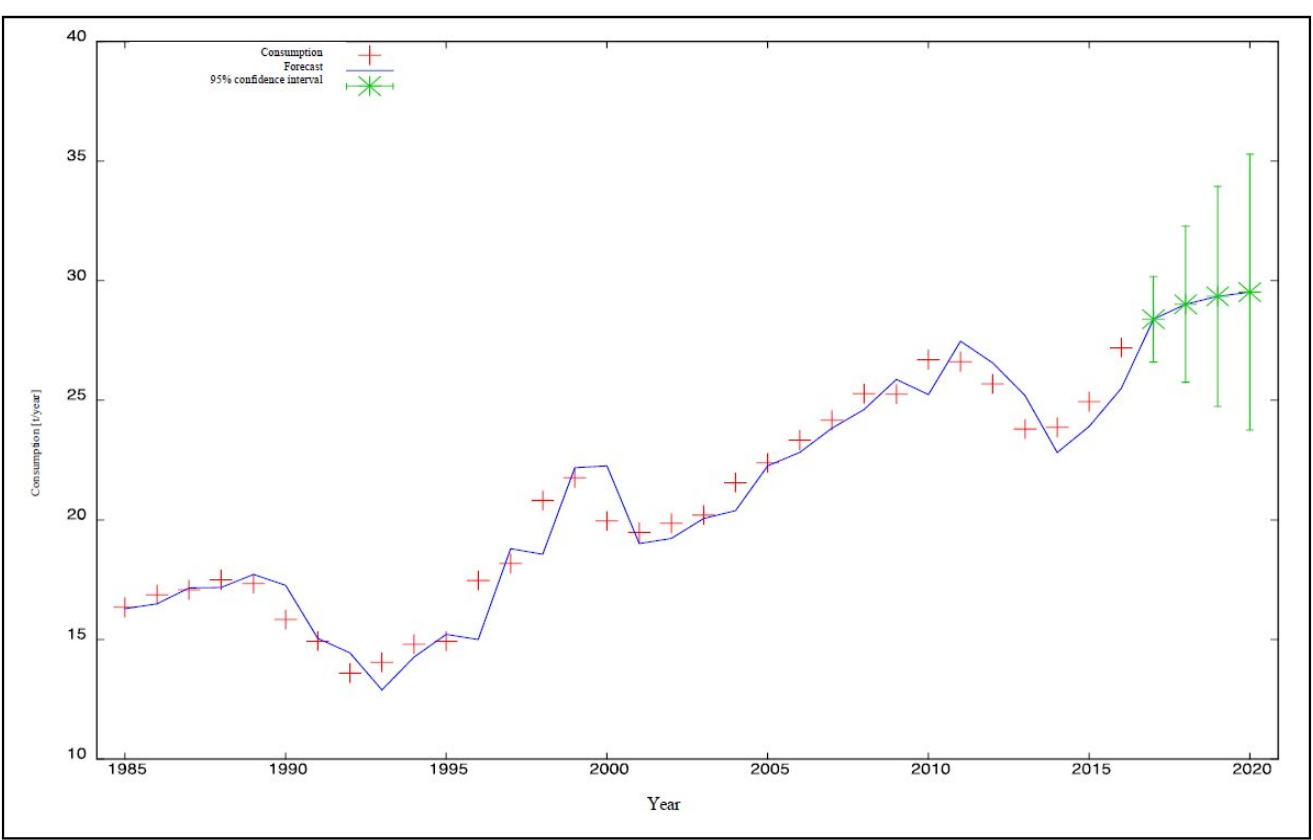

Fig. 7. Demand for crude oil in Poland with the forecast by 2020 ARIMA model $(1,1,0)$ (SRWE 2018)

Rys. 7. Zapotrzebowanie na ropę naftową w Polsce wraz z prognozą do roku 2020 model ARIMA $(1,1,0)$ 
sist in limiting the amount of crude oil extraction and accelerated pace of economic development in the world mainly because of China. A forecast for crude oil prices was created on the basis of historical data since the year 2016. SARIMA $(1,1,1)(0,1,1)$ model was used to prepare the forecast for crude oil prices (Fig. 8).

The model is burdened with a small prediction error:

$\downarrow$ The mean percentage error MPE $=0.23 \%$,

$\downarrow$ The mean absolute percentage error MAPE $=1.02 \%$.

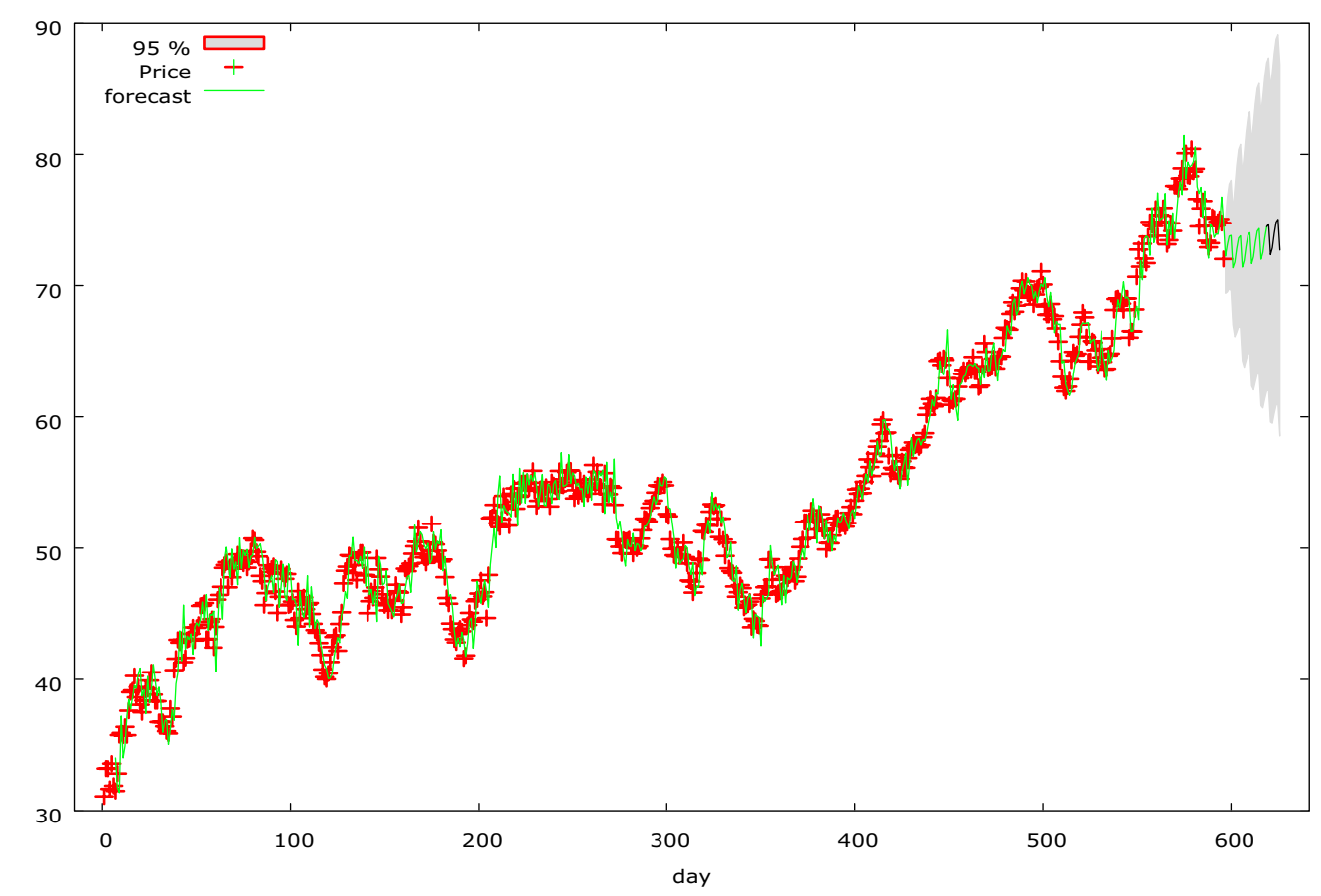

Fig. 8. The price of Brent-Europe crude oil from 2016-01-02 together with the forecast until July 1, 2018 (EIA 2018 )

Rys. 8. Cena ropy naftowej Brent-Europe od 02.01.2016 roku wraz z prognozą do 01.07.2018 r.

The model suggests that the growing trend in crude oil prices should be maintained in the near future. If the pace of price growth is not upset by any unforeseeable factor, the price of crude oil should exceed USD 100 in about two years. The price of crude oil is of key significance in the context of its position in the energy balance (Zhao et al. 2017).

In Poland, we have observed a decrease in $\mathrm{CO}_{2}$ emission which amounts to ca. $4 \%$ in the last four years which we owe to, among others, an increase of energy efficiency of the technologies in use. In accordance with the prevailing megatrends, the reduction of $\mathrm{CO}_{2}$ will still be necessary in the coming years. Considering the fact that in comparison with coal crude oil emits only slightly less pollutants, there are better coal substitutes, such as natural gas. 


\section{Crude oil or coal?}

If a necessity to replace one of the carriers of primary energy occurred, would the substitution of crude oil for coal and the other way round be possible in the energy mix? In theory, it would be possible because there are technological possibilities which enable such substitution. Below, the authors examined the most important ones.

\subsection{Liquid fuels}

In Poland, over $70 \%$ of crude oil is used to produce diesel fuels and $21 \%$ to produce motor fuels (Fig. 9). Crude oil and coal are the two most important sources of primary energy in the world. Coal constituted the foundations of the Industrial Age. Steam engines that were initially used were replaced by engines that were powered by liquid fuel based on crude oil (after the discovery of crude oil). This state of affairs has been preserved to this day, since coal combustion generates more pollutants, its exploitation is usually complicated and costly (especially deep exploitation of hard coal), and its shipment is difficult and demanding (Zamani 2016). In the periods of risk of crude oil unavailability due to the unfavorable location of its deposits for Europe, attempts were made to produce fuels with the use of coal, e. g. on the basis of the Fischer-Tropsch process (Davis 2001). This technology was developed at the beginning of the $20^{\text {th }}$ century because it was used by the Third Reich during World War II. However, factories and systems were destroyed during the war and crude oil prices in the 1950s resulted in abandoning of the idea. RSA was an exception because there this technology was developed by the Sasol company which continues to this day (Czaja 2014). Another and currently popular technology enables an in situ coal gasification. However, the geological conditions of Polish hard coal deposits create significant limitations and difficulties for underground gasification. The technology is burdened with additional difficulties caused by the migration of toxic gasification products into the rock mass (with the current state of knowledge). The hydrogen that is produced in this way can be used as the power source for car engines. The hydrogen supply has many advantages, even with reference to the electric cars: the charging time is shortened and the fuel is clean while electric energy that powers electric cars is not always created without greenhouse gas emission. The first hydrogen stations are currently being created all over the world. PKN Orlen is also engaged in their construction in Germany. 


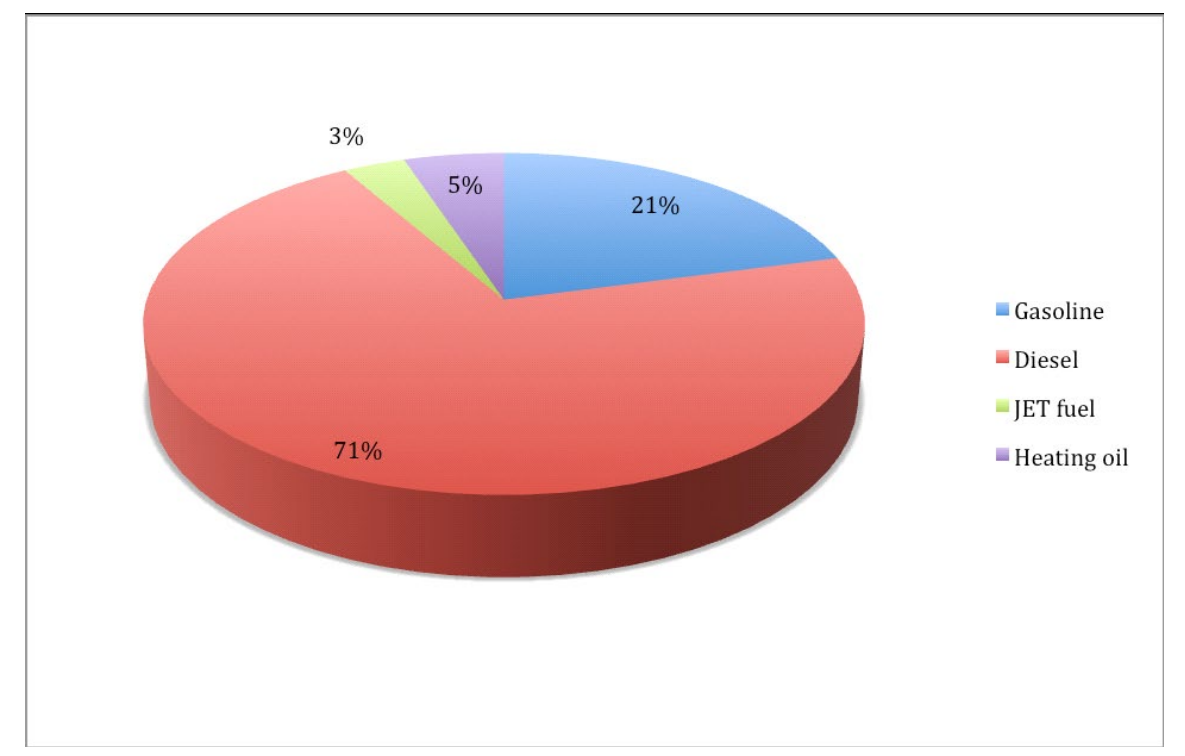

Fig. 9. The consumption of liquid fuels in after the Q1 of 2018 (POPIHN 2018)

Rys. 9. Konsumpcja paliw ciekłych w Polsce po pierwszym kwartale 2018 roku

\subsection{Use of crude oil for heating purposes}

Burning oil is used for heating industrial furnaces, process furnaces, and central heating boilers. Using burning oil is much more expensive than using coal for this purpose. The cost of acquiring $1 \mathrm{kWh}$ through oil combustion amounts to PLN 0.25 minimum (Ecoterm Plus), in the case of hard coal it amounts to PLN 0.15 on average. Thus, the cost is 60\% higher (PEC 2018).

\subsection{Electric energy}

Since the year 2006, the share of petroleum products in electric energy production in Poland has remained at a constant level of 1-2\%. In accordance with the forecast of the Polish Ministry of Energy, it is predicted that this level will be maintained by the year 2030 (MG 2009). Usually, the level of oil prices does not support the idea of transforming infrastructure into one that is based on crude oil because this is a costly undertaking. At present, such a possibility would potentially exist, however, it would involve huge expenditure and a long completion time of the investment. As the created oil prices forecast indicates, their consistent increase in the near future has to be taken into account. Crude oil imports would have to be increased by almost one third. 
Taking the forecast for crude oil prices into consideration, before completing the modernizations the prices could already be too high. On the global scale, the production of electric energy with the use of crude oil also remains at a very low level. After the 1973 oil crisis, newly emerging power plants produced coal-fired electric energy or were nuclear power and gas plants. Until 1985, crude oil use decreased by ca. $70 \%$.

\section{Summary and conclusions}

Among all primary energy carriers, crude oil is a fuel with the broadest spectrum of application (is a source of motor gasolines, diesel oil, heating oil, electricity, is an irreplaceable raw material for the chemical industry). This feature has resulted init becoming the principal energy source in the world. In Poland, due to the access to large deposits, the power industry is based on lignite and hard coal (Wagner 2016). More than $48 \%$ of primary energy and about $80 \%$ of electric energy that Poland consumes are produced from these resources (SRWE 2018). Owing to this fact, Poland's energy security lies with native resources which guarantees a continuity of supplies. However, the necessity of reducing greenhouse gas emissions forces a search for coal substitutes which could take over its key role in the Polish power industry. The article presents deliberations on crude oil as the substitute of hard coal. On account of the fact that crude oil is almost $100 \%$ imported in Poland, a reverse situation was also taken into consideration. With reference to assessment factors that were described in the introduction, the following conclusions were drawn:

The deposits that are available in Poland and their exploitation cover only a small part of the demand for crude oil. With regard to the above conclusions, for now crude oil is disqualified as the coal substitute because of the availability aspect. Regarding the total lack of access to imported oil, there are technologies that enable the conversion of hard coal into liquid fuel which could successfully replace crude oil.

Currently, crude oil prices are record low which allow them to compete with coal prices. However, the created forecasts suggest that this is only a temporary situation. The analysis of the time series of coal and oil prices since 1985 demonstrates that USD/toe oil price exceeded the coal price several times in the past. Therefore, it can be predicted that now the prices could encourage coal to be replaced with crude oil in the energy mix. But there is a risk that before the appropriate infrastructure was built, this situation would be useless in economic terms. Considering the use of crude oil in the aspect of cleanliness of the combustion process, it emits only slightly less greenhouse gases than hard coal so such a substitution seems to be pointless also in this regard. With respect to the necessity of reducing greenhouse gas emission, other solutions, which would be more adequate from an ecological point of view, should be found. In addition, remedies should be prepared before resources of the basic energy carriers are depleted. Renewable energy 
sources may be a solution, but they could constitute the basic energy source on the planet only in a very distant time horizon (Paska 2014). Nevertheless, transformation of infrastructure which is based on oil, coal, and natural gas will require time and financial outlays.

Natural gas is the best alternative for crude oil, lignite, and hard coal. (its combustion produces the smallest amount of $\mathrm{CO}_{2}, \mathrm{NO}_{\mathrm{x}}$ ). The combustion of blue fuel is a perfect solution from an ecological point of view, but its resources are too limited to plan the distant future of the Polish power industry based on natural gas. The future of shale gas is also uncertain in our country (Johnson 2013).

Plans concerning including nuclear energy in Poland's energy mix date back to the 1980s. Although this idea is taken into account in energy policy, its realization is constantly postponed. The construction of nuclear power plant requires appropriate technology, considerable financial outlays, and nuclear fuel which would also have to be imported. Moreover, all attempts to select a location for the power plant encounter social opposition. The necessity of storing nuclear waste also arouses controversy.

There is also the possibility of applying the so-called clean coal technologies that allow the greenhouse gas emissions generated during coal combustion to be reduced. At present, they are not applied on a mass scale because using this type of technology involves additional expenditures. However, taking into account the facts that technologies have been developing faster and faster, are modernized in a shorter time, that the earlier making of a breakthrough discovery took hundreds of years while now it often takes just a few months, clean coal technologies can become the optimal solution in the near future. The pace of energy carriers consumption increases in connection with China's and India's development. The amount of energy consumption in individual countries depends on the level of economic and civilizational development as well as the structure and effectiveness of energy use and the number of inhabitants. Considering the fact that hard coal resources should last for more than 200 years and that there are possibilities of applying technologies which can reduce coal's negative impact on the natural environment, it should be stated that coal can be perceived as the guarantor of energy security in Poland and in the world.

\section{References}

CZAJA, P. 2014. Black Africa, black coal, and golden fuel. A few words on coal gasification in the Sasol company - RSA (Czarna Afryka, czarny węgiel i złote paliwo. O zgazowaniu węgla w koncernie Sasol-RPA - słów kilka). Przegląd Górniczy vol. 11, pp. 132-141 (in Polish).

DAVIS, B.H. 2001. Fischer-Tropsch synthesis: current mechanism and futuristic needs. Fuel Processing Technology 71(1-3), pp. 157-166.

EIA 2018. [Online] https://www.eia.gov/dnav/pet/hist/RBRTED.htm [Accessed: 2018-06-20].

ERM 2011. Energy Raod Map 2050. Brussels: Publications Office of the European Union (EMR), 189 pp.

EUROSTAT 2017. [Online] http://ec.europa.eu/eurostat/statistics-explained/index.php?title=File:Energy_dependency_rate_all_products,_2005_and_2015_(\%25_of_net_imports_in_gross_inland_con- 
sumption_and_bunkers,_based_on_tonnes_of_oil_equivalent)_YB17.png\#file [Accessed: 2018-08$15]$.

GAWLIK et al. 2015 - GAWLiK, L., SzURLEJ, A. i WYRWA, A. 2012.The impact of the long-term EU target for renewables on the structure of electricity production in Poland. Energy 92, pp. 172-178.

Johnson, C. and Boersma, T. 2013. Energy (in)security in Poland the case of shale gas. Energy Policy 53, pp. 389-399.

KoT et al. 2007 - Kot, S., JAKUBOwSKi J. and SoKOŁOWSKI, A. 2007. Statistics (Statystyka). Warszawa: Difin, p. 528 (in Polish).

KUCHLER, M. and BRIDGE, G. 2018. Down the black hole: Sustaining national socio-technical imaginaries of coal in Poland. Energy Research \& Social Science 41, pp. 136-147.

KufEL, T. 2004. Econometrics. Problem solving with the use of Gretl software (Ekonometria. Rozwiazywanie problemów z wykorzystaniem programu Gretl). Warszawa: Wyd. Naukowe PWN, 212 pp. (in Polish).

LESZCZYŃSKI, T. 2012. Energy security index (Wskaźniki bezpieczeństwa energetycznego). RurociagiPipelines 2(66), pp. 3-10 (in Polish).

MG 2009. Forecast of demand for fuels and energy for a year 2030 (Prognoza zapotrzebowania na paliwa i energię do roku 2030). Załącznik 2 do Polityki energetycznej Polski do 2030 roku. Warszawa: Ministerstwo Gospodarki, 19 pp. (in Polish).

NeY, R. 2006. Crude oil resources (Zasoby ropy naftowej). Polityka Energetyczna - Energy Policy special issue 9, pp. 1429-6675 (in Polish).

Orlen 2018. [Online] Available at: http://www.orlen.pl/PL/Strony/default.aspx [Accessed: 2018-01-24].

PASKA, J. and SURMA, T. 2014. Electricity generation from renewable energy sources in Poland. Renewable Energy 71, pp. 286-294.

PE 2006 [Energy Law 2006]. Ustawa z dnia 10 kwietnia 1997 r. Prawo energetyczne [Act of 10 April 1997 on Energy Law]. (Dz.U.2006.89.625 ze zm.) [Journal of Laws Dz.U. 2006.89.625 as amended].

PEC 2018. [Online] http://pec.suwalki.pl/kalkulator.php [Accessed: 2018.01.20].

POPIHN 2018 [Polish Oil Industry and Trade Organisation 2018] - Consumption of liquid after the first quarter of 2018 (Konsumpcja paliw ciektych w Polsce po I kwartale 2018). Warszawa: Polska Organizacja Przemysłu i Handlu Naftowego, p. 1 (in Polish).

PIG-PIB 2017 - The balance of mineral resources deposits in Poland (Bilans zasobów złóz kopalin w Polsce). Warszawa: Państwowy Instytut Geologiczny - Państwowy Instytut Badawczy (PIG-PIB), 29 pp. (in Polish).

PiŁATOWSKa, M. 2010. Information criteria in selection of econometric model (Kryteria informacyjne w wyborze modelu ekonometrycznego). Kraków: Studia i Prace Uniwersytetu Ekonomicznego w Krakowie no. 10, pp. 25-37 (in Polish).

SRWE 2018. Statistical Review of World Energy. [Online] http://www.bp.com/en/global/corporate/energy -economics/statistical-review-of-world-energy.html [Accessed: 2018-01-09].

WAGNER et al. 2016 - WAGNER, A., GROBELSKI, T. and HAREMBSKI, M. 2016. Is energy policy a public issue? Nuclear power in Poland and implications for energy transitions in Central and East Europe. Energy Research \& Social Science 13, pp. 158-169.

Zamani, N. 2016. The Relationship between Crude Oil and Coal Markets: A New Approach. International Journal of Energy Economics and Policy 6(4), pp. 801-805.

ZELIAŚ et al. 2004 - ZELIAŚ, A., PAWEŁEK, B. and WANAT, S. 2004. Economic forecasting - theory, examples, objectives (Prognozowanie ekonomiczne - teoria, przyktady, zadania). Warszawa: Wyd. Naukowe PWN, p. 380 (in Polish).

ZHAO et al. 2017 - ZhAO, L., YAN, J., Cheng, L. and WANG, Y. 2017. Empirical study of the functional changes in price discovery in the Brent crude oil market. Energy Procedia 142, pp. 2917-2922. 


\title{
Przyszłość ropy naftowej i węgla kamiennego w aspekcie bezpieczeństwa energetycznego Polski
}

\author{
Streszczenie
}

W artykule przedstawiono syntetyczną analizę rynku ropy naftowej w Polsce. Badania te mają niezwykle istotne znaczenie w kontekście zapewnienia bezpieczeństwa energetycznego Polski. Obecnie bezpieczeństwo to jest utrzymywane głównie na podstawie rodzimego węgla brunatnego i kamiennego. Przeprowadzona przez autorów analiza rynku węgla kamiennego wskazuje jednak, iż prowadzona restrukturyzacja górnictwa doprowadziła do nadmiernej redukcji wydobycia oraz zatrudnienia w sektorze górnictwa węgla kamiennego. Wywołało to precedensową sytuację, kiedy to Polska stała się importerem netto tego nośnika energii. Dodatkowo należy wziąć pod uwagę wymagania Unii Europejskiej w zakresie emisji gazów cieplarnianych. W związku z powyższym konieczne staje się poszukiwanie nowych źródeł energii bądź technologii umożliwiających węglowi kamiennemu sprostanie stawianym wymaganiom. Istnieje możliwość zastosowania tzw. czystych technologii węglowych pozwalających na ograniczenie emisji gazów cieplarnianych powstających podczas spalania węgla. Na dzień dzisiejszy nie są one stosowane na skalę masową, ponieważ korzystanie z tego typu technologii wiąże się z dodatkowymi nakładami finansowymi. Jednak biorąc pod uwagę, że w ostatnim czasie technologie rozwijają się coraz szybciej, są unowocześniane w coraz krótszym czasie, kiedyś przełomowe odkrycia dzieliły setki lat, dekady - teraz powstają one w rekordowym tempie nawet kilku miesięcy, to czyste technologie węglowe mogą stać się optymalnym rozwiązaniem już w niedalekiej przyszłości. Konieczne jest również zdywersyfikowanie źródeł pozyskania importowanych nośników energii. W artykule scharakteryzowano węgiel oraz ropę naftową pod kątem możliwości ich wzajemnej substytucji. Artykuł stanowi kontynuację prowadzonych przez autorów badań. Przeanalizowano rynek ropy naftowej w Polsce oraz zaprezentowano prognozy wielkości wydobycia i zapotrzebowania na ropę naftową na świecie i Polsce do roku 2023. Utworzono także model SARIMA, który umożliwił pozyskanie prognozy cen ropy naftowej.

We wcześniejszych publikacjach przedstawiono rozważania o analogicznej tematyce odnośnie do gazu ziemnego oraz odnawialnych źródeł energii.

SŁOWA KLUCZOWE: rynek ropy naftowej, surowce energetyczne, model ARIMA 